\section{Cluster Analysis of Customer Satisfaction at PT Esta Dana Ventura, Indonesia}

International Journal of Economics, Business and Management Studies Vol. 6, No. 1, 26-32, 2019 e-ISSN: 2226-4809/p-ISSN: 2304-6945

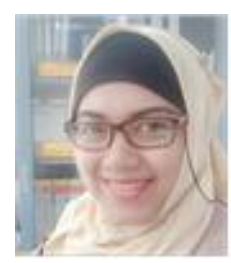

(\&) Corresponding Author)

\author{
Syahnaz ${ }^{1}$ \\ (D) DhianTyas Untari ${ }^{2}$ \\ M.Fadhli Nursal ${ }^{3}$ \\ NengSiti Komariah ${ }^{4}$
}

'Student of Faculty of Economic, Bhayangkara Jakarta Rata University, Indonesia. ${ }^{2,3,4}$ Lecture of Faculty of Economic, Bhayangkara Jakarta Rata University, Indonesia. ${ }^{2}$ Email: tyas_un@yahoo.co.id

\title{
ABSTRACT
}

The purpose of this study is to determine the level of customer satisfaction with service attributes at PT. Esta Dana Venture (physical evidence, reliability, responsiveness, assurance, and empathy). This study involved 220 respondents, where research involved PT Esta Dana Ventura consumers in the category of landing credit debtors. Data analysis methods use the Important Performance Analysis (IPA) model. Based on the results of primary data recapitulation, in general, consumers are quite satisfied with the services provided, where the number of the existing performance is greater than the expectation given by consumers. The results of the study show that the variables are the Empathy and Tangible are the first quadrants, which means very good, while the responsiveness and reliability are the second levels which mean they are not too optimal, while the assurance variable as in the third quadrant means that it is still bad. With the results of this study, it is expected that PT Esta Dana Ventura can further optimize its marketing strategy in order to compete with similar companies.

Keywords: Important performance analysis (IPA), Banking, Cluster analysis, Bekasi, West Java, Indonesia JEL Classification: G21.

DOI: $10.20448 / 802.61 .26 .32$

Citation | Syahnaz; DhianTyas Untari; M.Fadhli Nursal; NengSiti Komariah (2019). Cluster Analysis of Customer Satisfaction at PT

Esta Dana Ventura, Indonesia. International Journal of Economics, Business and Management Studies, 6(1): 26-32.

Copyright: This work is licensed under a Creative Commons Attribution 3.0 License

Funding: This study received no specific financial support.

Competing Interests: The authors declare that they have no competing interests.

History: Received: 14 January 2019/ Revised: 21 February 2019/ Accepted: 29 March 2019/ Published: 16 May 2019

Publisher: Online Science Publishing 


\section{INTRODUCTION}

The crisis that hit Indonesia in 1997 began with the crisis of the rupiah exchange rate against the US dollar and the monetary crisis had a very significant impact on the development of micro, small and medium enterprises (MSMEs) in Indonesia. The high value of the US dollar has a major impact on people's lives, this is because the majority of products circulating in the community are imported products and are made from imported raw materials. So the price of imported products or imported raw materials is not affordable by the ability of the community (Soesastro and Basri, 2005).

The decline in people's purchasing power due to the crisis has become an opportunity for the community to start a business or become an entrepreneur. The community creates substitute products to meet the demand for imported products whose prices soar beyond the ability of consumers (Kinnear and Taylor, 2003) so that small businesses begin to grow in Indonesia. Based on the cooperative ministry data, the contribution of the MSME sector to gross domestic product is $60.34 \%$ (BI, 2016).

The contribution of Indonesian MSMEs to global product supply is only 2.7\%, this shows that the condition of Indonesian MSMEs is far behind if it is with MSMEs in ASEAN countries (BI, 2016). The small contribution of MSMEs in Indonesia compared to other countries is due to various problems that surround small businesses, such as capital, marketing, production, human resources and others. Various challenges faced by small businesses need to be solved and sought solutions so that small businesses are able to take advantage of the opportunities that exist. The role of government and society is very important to support small businesses to achieve competitive advantage so they can compete with other countries' MSMEs.

Financing is the main obstacle faced by MSMEs in this country in achieving competitive advantage both locally and globally. Whereas in various countries this problem has been resolved well with various non-bank financing alternatives, while in Indonesia banking is still the main source of capital for small businesses (BI, 2016). In some countries, small business financing sources are available without the need for collateral. The sources of funds come from Equity financings such as angel investors, venture capital, or private equity. These sources of financing not only exist in developed countries but also in developing countries such as Tanzania which has Tanzania Venture Capital, in Thailand has an SME Investment and Restructuring Fund (SIRF), Laos has a Mekong SME Fund (MSMEF) and many other countries that aim to finance and funding MSMEs without guarantees, the funds come from various sources both from private ventures, corporate social responsibility from various companies, the government and other sources (BI, 2016).

To overcome the capital problems of MSMEs in Indonesia, PT. Esta Dana Ventura engaged in the field of Non-Bank Financial Institutions with a model of venture capital/microfinance institute can help MSME entrepreneurs in providing capital financing with a profit-sharing system. The existence of the capital enrichment program is expected to be able to help MSME entrepreneurs in developing their businesses which ultimately help improve the welfare of MSME entrepreneurs (Latu and Everett, 2000).

In conditions of very tight competition in financing institutions, various financial institutions, both conventional and sharia, emerge and compete to meet financing needs and requirements. Then PT. Esta Dana Ventura must always strive to increase customer satisfaction by providing quality services. Customer satisfaction will be the main weapon of PT. Esta Dana Ventura in the face of competition, because satisfied customers will be able to attract other prospective customers to become consumers of PT. Esta Dana Ventura. The ability to win this competition will determine the ability of microfinance institutions to gain market share (Untari, 2016). Service quality is an action aimed at meeting the needs and desires of consumers or customers served. Good and bad service 
depends on the ability of PT. Esta Dana Ventura in providing good service in accordance with consumer financing expectations.

According to Ciptono (2000) to provide good quality service, there are several important elements, namely: First, the speed of service. Fast service and responsiveness to consumer desires will have an impact on the quality of service to customers. Second, Accuracy. This accuracy is related to the response in accordance with consumer needs, in addition to the timeliness of service. Third, friendliness, friendliness is related to employee attitudes in dealing with customers. Courteous, friendly, and neat employees will have an impact on customer satisfaction with the services provided. Fourth, comfort. Convenience is related to the place and facilities provided to consumers.

Customer satisfaction of PT. Esta Dana Ventura is the main objective of the services provided. Customers of PT. Esta Dana Ventura, which is mostly engaged in micro and small business, ranging from vegetable traders, rickshaw pullers, hawkers, grocery traders, home tailors, small craftsmen, masons, farmers, breeders, to relatively modern businesses need to get good service.

Customer satisfaction can determine the continuity of the business underway. With an analysis of customer satisfaction, the company can increase knowledge about what consumers feel and know the strengths and weaknesses of the company. When PT. Esta Dana Ventura knows what is the customer's needs then tries to measure the level of satisfaction, it will make it easier for PT. Esta Dana Ventura to implement its strategy. In order to meet customer expectations, PT. Esta Dana Ventura must provide quality-oriented services that always pay attention to customer satisfaction.

So in accordance with the above research, in this study, the author will take the title and examine "CLUSTER ANALYSIS OF CUSTOMER LEVELS, ESTA DANA VENTURA LEVELS". Based on this background, the aim is to determine the level of customer satisfaction with services at PT. Esta Dana Venture and know which attributes (tangibles, reliability, responsiveness, assurance, and empathy) should be the priority of service for customer satisfaction of PT. Esta Dana Ventura.

\section{METHODOLOGY}

The research design used in this research is quantitative descriptive which aims to identify customer satisfaction by looking at the quality of services provided by PT. Esta Dana Ventura. Quantitative descriptive study is a study to make observations with appropriate interpretations and includes studies using statistical analysis to accurately describe the properties of several group phenomena (Arikunto, 2006; Notoatmodjo, 2010).

This research was conducted in order to apply the SERVQUAL model which occurs in the fifth gap, namely the expected gap between services and services developed by Parasuraman et al., In 2017 Woestho to find out how the expectations of PT. Esta Dana Ventura before using services to the perception after feeling the service from PT. Esta Dana Ventura.

The study involved 80 respondents (according to Slovin formula), then the results of data collection were then analyzed using Importance-Performance Analysis (IPA). The first stage in the Importance-Performance Analysis (IPA) method is to determine the level of suitability between the level of importance and the level of performance of the quality of the attributes under study through a comparison of performance scores and score of interest (Untari, 2018).

The conceptual model is a concept of how the theory of relationships with various factors has been defined. The conceptual models in this study are: 


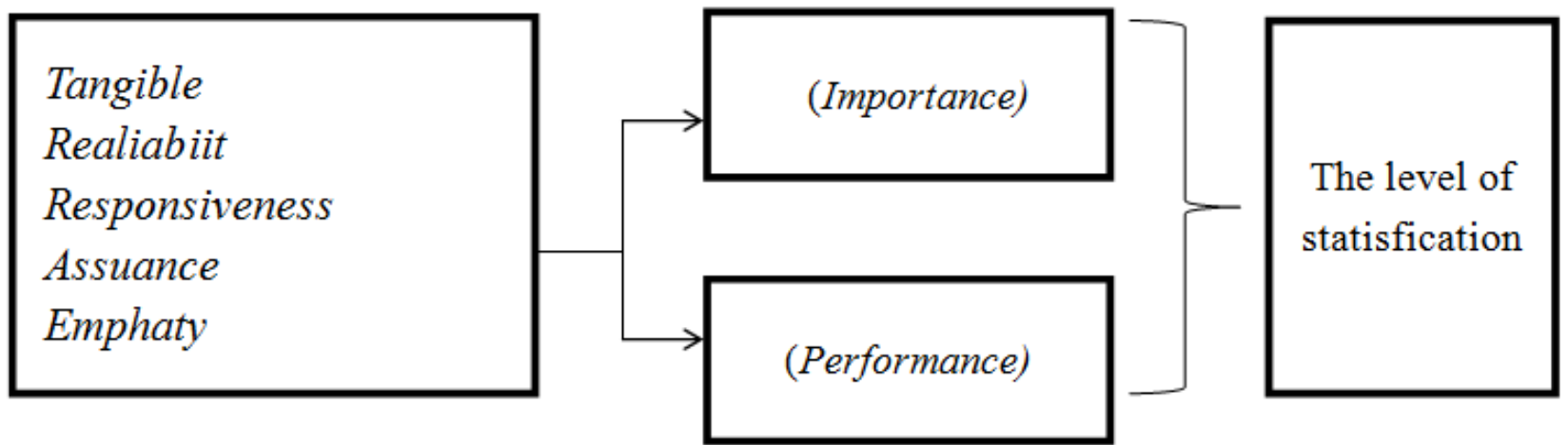

Source: Untari (2018).

Figure-1. Model of rating the level of customer satisfaction.

The operational variable definition is a definition of the variables formulated based on the characteristics of these variables which can be observed according to Azwar in 2017 Woestho. Operational definitions in this study include.

Reliability, namely the ability to provide accurately promised services, and the ability to be trusted dependable, especially in providing services in a timely manner, in the same way as promised and without making mistakes every time. The indicators of reliability in this study are:

a. The speed and accuracy of the receptionist in serving guests

b. Timely service hours (opening, resting and closing hours)

c. Provide information to consumers about when the promised service will be realized

d. Fast and precise service

Responsiveness is the willingness and desire of employees to help and provide services needed by consumers. Allowing consumers to wait, especially without clear reasons, will create a negative impression that should not occur. Unless this error is responded quickly, it can be a memorable and pleasant experience. The Responsiveness indicators in this study are:

a. Providing fast service

b. Availability of employees who help customers or guests

c. Ready and responsive to respond to requests from consumers

d. ready and responsive to respond to complaints from consumers

Assurance (guarantee), including knowledge, ability, friendliness, courtesy, and trustworthiness of personnel contacts to eliminate the nature of consumer doubt and feel free from danger and risk. The indicators of Assurance in this study are:
a. Friendliness of employees in serving customers or guests
b. Extensive knowledge
c. Make consumers feel safe when using company services
d. Guarantee the confidentiality of customer data

Empathy, including the attitude of contact personnel and companies to understand the needs and difficulties, consumers, good communication, personal attention, ease of communication or relationship. The Emphaty indicators in this study are: 

a. Give individual attention to consumers
b. Employees are able to communicate well with consumers
c. The clerk always understands the customer's needs

Tangibles (products / physical facilities), the availability of physical facilities, equipment, and means of communication, and others that must be present in the process of delivering services. The Tangibles indicators in this study are:
a. Building and interior conditions
b. Cleanliness and comfort of the company PT. Esta Dana Ventura
c. Complete facilities available from the company PT. Esta Dana Ventura.

In this study, the type of research instrument used was the questionnaire method. The type of data used is qualitative data which is estimated in the form of questionnaires and quantitative data. To obtain answers in the form of quantitative data to be processed statistically using a measurement scale, namely the Guttman scale. Sources of data in this study are primary data obtained from questionnaires to customers of PT. Esta Dana Ventura. The data analysis technique used in this study is to implement the Important Performance Analysis method, namely by doing quadrant analysis to show the relationship between the assessment of importance and level of performance. Calculate the value of the Customer Satisfaction Index to see the overall level of customer satisfaction.

\section{RESULTS AND FINDING}

Based on the results of questionnaire deployment, the results of the distribution of respondents' profiles were based on gender, education and income. Table 1 shows the recapitulation data of profile respondents and then Table 2 shows the recapitulation of the expectation and existing performance of PT Esta Dana Ventura.

\begin{tabular}{|c|c|c|c|c|c|}
\hline \multicolumn{2}{|c|}{ Gender } & \multicolumn{2}{|l|}{ Education } & \multicolumn{2}{|l|}{ Income } \\
\hline \multirow[t]{2}{*}{ Male } & \multirow[t]{2}{*}{51} & High School & 29 & $<3.000 .000$ & 11 \\
\hline & & Diplome & 20 & $3.000 .001-5.000 .000$ & 37 \\
\hline \multirow[t]{2}{*}{ Female } & \multirow[t]{2}{*}{29} & Bachelor & 31 & $5.000 .001-10.000 .000$ & 26 \\
\hline & & PostGrad & - & $>10.000 .000$ & 6 \\
\hline \multicolumn{6}{|c|}{ Source: Process data, 2019.} \\
\hline \multicolumn{6}{|c|}{ Table-2.Datas Recapitulation. } \\
\hline Variabl & & The expectation & $\mathbf{T}$ & existing performance & GAP \\
\hline Tangib & & 4 & & 4 & $\mathrm{O}$ \\
\hline Realiabil & & 3,4 & & 3,9 & 0,5 \\
\hline Responsive & & 3,5 & & 3,7 & 0,2 \\
\hline Assuan & & 3,1 & & 3,2 & 0,1 \\
\hline Empha & & 3,7 & & 4 & 0,3 \\
\hline C-Line & & 3,54 & & 3,76 & \\
\hline
\end{tabular}

Based on the results of primary data recapitulation, in general consumers are quite satisfied with the services provided; this can be seen from the figures of GAP, where the number of the existing performance is greater than the expectation given by consumers.

The highest existing performance scores on Tangible and Empathy variables. Thus it was concluded that aspects of the building, employee uniforms and all tangible aspects were considered very good by consumers. While 
the variable Assurance gets the existing performance score is the smallest (but still higher than consumer expectations). This shows that the guarantee aspects are considered imperfect, even though they are still in the good category. Mapping each variable is visualized in the following Figure 2.

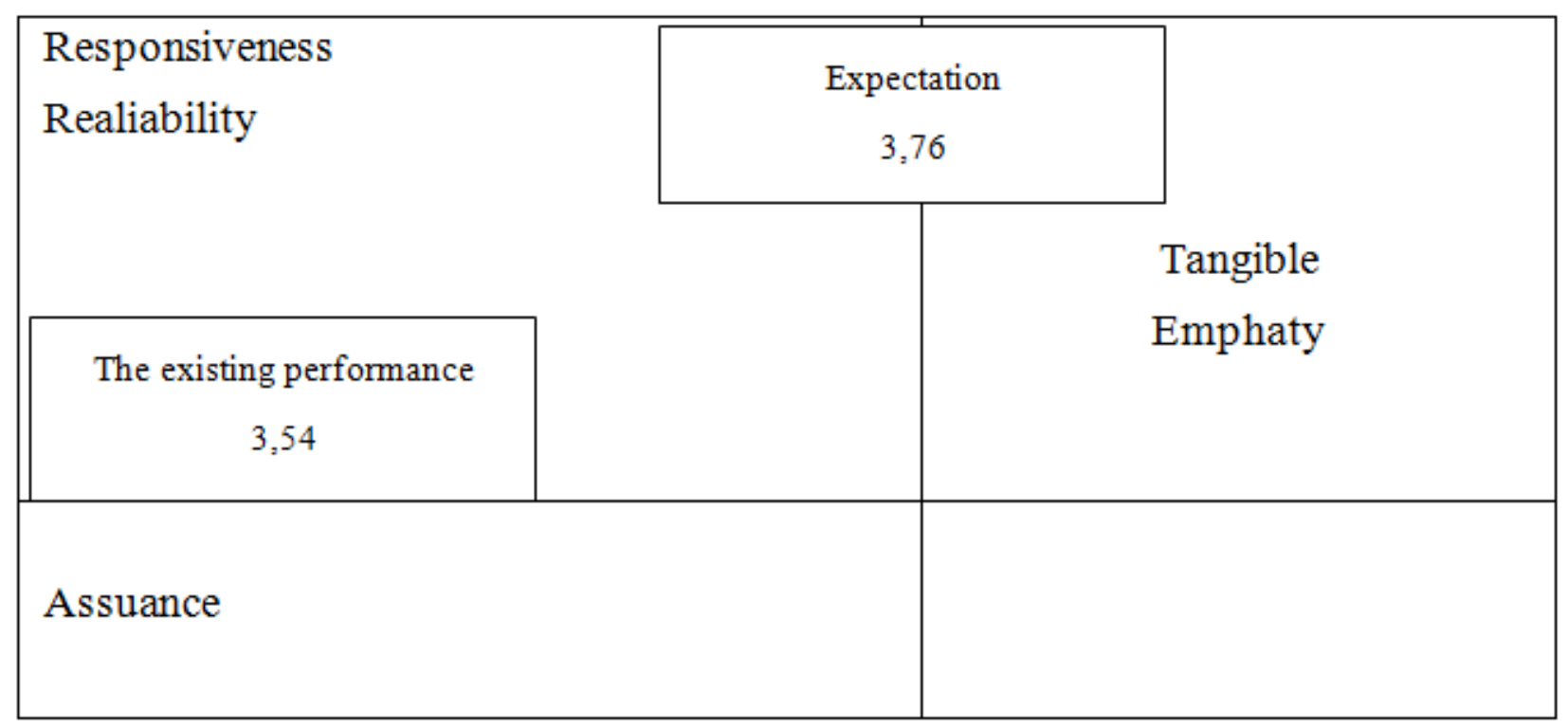

Source: Process data, 2019

Figure-2. Important Performance Analysis.

Based on the figure above, it can be seen that the Tangible and Empathy variables are in the same position and are perceived to be quite good, while the Responsiveness and Reliability are in the second quadrant, which can be interpreted that it is still not optimal. And the variable assurance is still far below the average and can be said to be very lacking.

\section{CONCLUSION}

In general, PT Esta Dana Ventura is perceived quite well by consumers. Of the five variables assessed the variables Empathy and Tangible are in the first quadrant, which means very good, while the Responsiveness and Reliability variables are in the second level which means they are not too optimal, while the assurance variable as in the third quadrant means that it is still bad. With the results of this study, PT Esta Dana Ventura can look for strategies that are quite relevant to improve the quality of its services.

\section{REFERENCES}

Arikunto, S., 2006. Research procedure (a practice approach). Jakarta: PT Asdi Mahasatya.

BI, 2016. Mapping and strategy for increasing MSME competitiveness in facing the ASEAN Economic Community (2015) and Post-MEA 2025. Bank Indonesia; Indonesia.

Ciptono, F., 2000. Marketing strategy. Yogyakarta: Andi Offset.

Kinnear, T.C. and J.R. Taylor, 2003. Marketing research, (Translation by Thamrin). 3rd Edn., Jakarta: Erlangga.

Latu, T.M. and A.M. Everett, 2000. Review of satisfaction research and measurement approaches. Wellington, New Zealand: Departement of Conservation.

Notoatmodjo, S., 2010. Health behavior sciences. Jakarta: PT Rineka Cipta.

Soesastro, H. and M.K. Basri, 2005. The political economy of trade policy in Indonesia. Economics Working Paper Series. 
Untari, D.T., 2016. The potential development of Betawi Culinary as an ecotourism product in Jakarta. Binus Business Review, 7(3): 275-280.Available at: https://doi.org/10.21512/bbr.v7i3.1532.

Untari, D.T., 2018. DIAN (Dimentional Analysis); to analyzing patterns polarization of perception, motivation and preferences to develop the ecotourism Betawi Traditional Culinary. Journal of Economic Development, Environment and People, 7(4): 6-15.Available at: https://doi.org/10.26458/jedep.v7i4.593.

Online Science Publishing is not responsible or answerable for any loss, damage or liability, etc. caused in relation to/arising out of the use of the content. Any queries should be directed to the corresponding author of the article. 